\title{
Universally speaking: Lost in Translation and polyglot cinema
}

\author{
Tessa Dwyer \\ University of Melbourne
}

Conceived from the start as a cultural form with mass, international appeal, cinema bears a fascinating relationship to translation, both real and figurative. From the days of the silents and early talkies to contemporary new Hollywood, this paper explores the nature of this relationship through reference to Lost in Translation and the wider polyglot genre. Revelling in the comic and poetic potential of inter-cultural (mis)communication, Lost in Translation (2004) directs attention towards the messy and mundane realities of translation, thereby exposing the industry's more usual predilection to ignore or disavow the complexities of language difference. Comparing Lost in Translation to cinematic predecessors such as Le Mépris / Contempt (1963) and 1930s polyglots, this discussion seeks primarily to challenge the myth that the language of cinema is universal.

\section{Subtitles and samurai}

In January 2004, the New York Times pondered the recent spate of Japanesethemed Hollywood productions gracing cinema screens worldwide, citing Kill Bill (dir. Quentin Tarantino, 2003-2004), The Last Samurai (dir. Edward Zwick, 2003) and Lost in Translation (dir. Sofia Coppola, 2003) as examples. ${ }^{1}$ According to Motoko Rich (2004: A2, 3), this "season of subtitles and samurai" sparked "heated debate, particularly among Asian-Americans and Japanese, about whether Hollywood's current depictions of Japan are racist, naïve, well-intentioned, accurate, or all of the above". The Hollywood 'dream factory' has been trading in images of otherness, wholesale stereotypes and cultural clichés since its emergence in the early part of the $20^{\text {th }}$ century and despite the current climate of globalisation it is fair to suggest that not much has changed. The exotic lure of the foreign, indicated through geographic, cultural and/or linguistic markers, in many ways represents the backbone of the cinema industry and, as I will argue, has done so since its inception.

The interesting issue that Rich highlights is not Hollywood's treatment of Japanese culture, but rather, its current relation to language. For Rich, it is language, specifically the presence of foreign language, which signals a new global sensibility. The films she cites as characteristic of new Hollywood all sport scenes incorporating language contact, where two or more languages meet. Most importantly of all, this multilingualism is visible in the narrative, marked by the use of an interpreter or through subtitled or untranslated dialogue. In the US, this situation is indeed remarkable. America's historical rejection of subtitling - and more general lack of inter- 
est in foreign-language films - represents a fascinating chapter in a discussion of the myriad ways in which translation techniques have been taken up by different nations. As Ruby Rich (no relation) details, America's monolinguistic movie-going habit needs to be understood within a social framework which takes into account the country's widespread lack of foreign-language ability. The marketing ploy of releasing dialogue-free, no-translation trailers for foreign-language films in order to dupe audiences is a case in point (R. Rich 2004: 163). The New York Times article draws attention to the fact that subtitles and foreign languages in general are currently enjoying a new visibility. $^{2}$

According to Bennet Schaber (2005) this linguistic turn is a distinguishing feature of 'new global cinema' of which Lost in Translation is a prime example. Schaber asserts that contemporary global cinema is defined by its relation to language and translation. In his opinion, the best of such productions "gesture toward [...] not the dream of a fully transparent communication beyond translation, but the sphere of mis-translation, mis-communication as constitutive of the gap [...] in which understanding might appear" (Schaber 2005). As its title suggests, Lost in Translation is infused by multilingualism or language difference. The often-bumpy contact between languages (mainly English and Japanese) is evident in multiple, highly comic scenarios, which serve as a background effect or leitmotif upon which broader, non-linguistic forms of differentiation take place. Together, Bob Harris (Bill Murray) and Charlotte (Scarlett Johansson) experience the sensation of being culturally and linguistically out-of-synch, their sense of difference reinforced through an array of scenes revolving around the trials of miscommunication, disarticulation and the unintelligible.

The fictionalised language contact of Lost in Translation defines it as belonging to the polyglot genre, which developed hand in hand with the coming of sound in the late 1920s - early 1930s. Polyglot films are marked by the naturalistic presence of two or more languages at the level of dialogue and narrative. Kameradschaft / La Tragédie de la mine (dir. G.W. Pabst, 1931), for instance, is set around a coal mine situated on the newly negotiated French/German border in the aftermath of WW1. When disaster strikes, linguistic and cultural differences are set aside and a common humanity discovered. As early as 1929, Paramount is reported to have produced a fourlanguage talkie (Danan 1999: 229). Other early examples include Niemandsland / No Man's Land (dir. Victor Trivas, 1931) and Allo Berlin? Ici Paris! / Hallo Hallo - Hier Spricht Berlin! (dir. Julien Duvivier, 1931-1932). During this time, the polyglot was only one of a number of multilingual strategies employed in order to solve the international problem posed by sound. Other practices included foreign remakes (still popular today) and the largely obsolete multiple-language version or MLV, which I discuss below.

Attempting a first 'approximate' definition and description of the genre, Chris Wahl (2005) notes the polyglot's particularly European dimension and proposes that, since the 1990s, it has been experiencing a "new 
wave' amongst filmmakers seeking to represent conditions of migrant and diasporic existence. Some contemporary examples include Night on Earth (dir. Jim Jarmusch, 1991), Calendar (dir. Atom Egoyan, 1993), Lisbon Story (dir. Wim Wenders, 1994/5), Kurz und Schmerzlos (dir. Fatih Akin, 1998) and Nirgendwo in Afrika (dir. Caroline Link, 2001). Wahl suggests that 'genuine' polyglots are "anti-illusionist in the sense that they do not try to hide the diversity of human life behind the mask of a universal language". In this sense, Lost in Translation and the wider polyglot genre provide a succinct entry to a range of broader questions concerning the nature of film and/as translation. By highlighting issues of language contact in its narrative, plot and dialogue, Lost in Translation reverses the industry's more usual tendency to ignore or deny issues of language difference. Its rare foregrounding of translation in action (detailing all the messy realities that such practices entail) exposes one of the cinema's founding myths: that it speaks a universal language.

In proposing to examine the multilingual environment of the polyglot film, this paper hopes to suggest a possible interface between the disciplines of Film Studies and Translation Studies. It seeks to briefly document some actual historical and contemporary film translation practices while considering the impact of such practices on the development of film culture as a whole. In this sense, my project could be identified as part of the co-called 'cultural turn' currently affecting translation discourse, as explored in André Lefevere and Susan Bassnet's anthology Translation, History and Culture (1990). Film's audiovisual composition challenges the textual focus of much translation scholarship, while its mass cultural dimensions disturb notions of quality and cultural prestige, traditionally so crucial to the definition and defence of translation (Delabastita 1990: 97). In keeping with Lefevere and Bassnett's (1990: 11) view that this 'cultural turn' has seen "issues of context, history and convention" assume primacy over formal linguistic and literary approaches, it is my aim to examine the affect of translation on film history and culture rather than to partake in any type of comparative study between 'original' films and translated ones, or to debate the merits of varying translation techniques. Indeed, as film scholar Mark Betz reveals, the complicated nature of international film production and distribution often invalidates the very concept of an original. ${ }^{3}$ Finally, this project owes much to others currently examining inter-cultural modes of film production and consumption, such as theorists Betz (2001), Rey Chow (1995), Natasa Durovicova (1992), Richard Maltby \& Ruth Vasey (1994), Hamid Naficy (1996), and Ella Shochat \& Robert Stam (1985).

\section{Cute arses}

Lost in Translation opens with the shot of a woman in repose seen from behind wearing a green top and muted, slightly see-through, pink underpants. The camera lingers in close-up on her bottom while the opening 
credits roll and the soundtrack begins. Finally the film's title appears like a subtitle itself, occupying the lower third of the screen. The shot ends and the film cuts to the story of Bob Harris, the aging Hollywood actor travelling to Tokyo to shoot a lucrative whiskey commercial.

The significance of this introduction is revealed when considered in relation to the earlier polyglot production Le Mépris / Contempt (dir. JeanLuc Godard, 1963). As Wendy Haslem (2004) notes, Lost in Translation's opening shot deliberately echoes Le Mépris' extended prologue in which international superstar Brigitte Bardot lies naked on an unmade bed next to co-star Michel Piccoli. As Godard experiments with colour filters, Bardot's bottom remains centre stage, the dialogue playfully pointing out the blatant voyeurism of the scene. "Do you think I have a cute arse?", Camille (Bardot) enquires of her fully clothed husband Paul (Piccoli). According to Haslem (2004), "Coppola's intention with this opening shot appears to be to defy taboos and to undermine expectations surrounding what might be considered the 'money shot' in more traditionally exploitative cinema". I would suggest however that this shot is far more significant in terms of Lost in Translation's awareness of and relation to global politics and positioning. The connection with Godard's Le Mépris cements the pivotal role of linguistic and cultural difference in this film and directs attention towards the complexities of a globalised, polyglot world.

Le Mépris is somewhat extraordinary in terms of the self-consciousness it displays. Although this trait is entirely typical of Godard's $2 u v r e$, here it reaches new heights. Essentially, Le Mépris is a film about a film, or more specifically, about a European-American co-production, which it itself is. Representing Godard's first big-budget, US-financed film featuring boxoffice stars (Bardot and Jack Palance) and based on the Italian novel Il disprezzo (1954) by Alberto Moravia, it remains thoroughly self-reflexive about the ramifications of working on such a scale and about the leap being made from art house to Hollywood. Throughout the film the US producer Jerry Prokosh (Palance) is depicted in a harshly critical, comical fashion. He quotes wise sayings from a pocket-sized collection, throws infantile tantrums, and is entirely lacking in cultural sophistication and artistic vision, constantly blocking auteur Fritz Lang (played by Lang himself). In this sense, the film mirrors the actual difficulties Godard was experiencing at the time with producers Carlo Ponti and Joseph E. Levine. According to Peter Lev (1993: 87-88), the opening scene featuring Bardot's naked figure (and "cute arse") was a concession to the producers who were otherwise disappointed by the way the film downplayed Bardot's sex goddess image.

It is through Le Mépris' female translator Francesca Vanini that the international politics of this film and of filmmaking in general find their most eloquent expression. Conversant in French, German, Italian and English, the translator represents the point at which competing cultures, egos and ideologies converge. While her linguistic dexterity enables her to mediate between these varying levels of meaning, she also, ironically, articulates a site of 
untranslatability. By fictionalising translation through the character of Francesca, Godard sought to make a film that was impossible to dub. If all characters speak the same language, the figure of the translator becomes redundant and the entire meaning of the film is forsaken. The strategy was successful in terms of the film's English-language release, yet proved no match to Italy's post-synchronization laws established in 1929, which decreed that all films screened in Italy had to comprise an Italian-language sound track (Durovicová 1992: 149). Godard reportedly disowned the dubbed Italian version (Shochat \& Stam 1985: 46).

The figure of the female translator provides another point of connection with Lost in Translation. The scene in which Bob shoots a whiskey commercial features a particularly frustrating and ineffectual female translator who repeatedly transforms the director's lengthy instructions to Bob into brief, nonsensical statements. Without any knowledge of Japanese language, Bob's protests (his meek question "That's all he said?" and his ironic acting style) go unheard and un-noted. While the pink wig that Charlotte dons in the karaoke scene visually recalls Bardot's black wig in Le Mépris, it is in terms of narrative that the more significant commonalities between these films emerge. The skeleton plot is basically identical: a young wife becomes disillusioned with her husband while in a foreign location and enters a liaison with an older man. The themes of language difference, international politics, filmmaking and self-discovery are also strikingly similar. It is the unfamiliar within the familiar (a new sense of dissatisfaction or contempt) that motivates both Charlotte and Camille's transformation.

Coppola's overt references to Le Mépris - the opening scene, the wig, the translator and the name of the central female protagonist - can be understood as signposts alluding to a deeper, overarching connection which acknowledges the polyglot dimension of Lost in Translation and the primacy of language in definitions of global culture. Although both films vary considerably in the way that language and translation are incorporated and deconstructed, they are united by the fact that in each, these issues assume primary importance, imbuing the tone, narrative pace and mise-en-scène, in addition to the dialogue track. For Godard, the impossibility of translation became a metaphor for the conscription of cinema in the service of international diplomacy. Along with other of his films such as Masculin/Feminin (1965) and Pierrot le fou (1965), Le Mépris uses language to criticise the way in which international co-production arrangements often prioritise economic and national interests over artistic ones. In Masculin/Feminin, a French/Swedish co-production, Godard circumvented the requirement that he cast Swedish actors (speaking a language he could not direct), by casting them in an unconvincing Swedish play within the film (Betz 2001).

As one would expect, Coppola's relationship to language and translation is entirely different to Godard's. Despite the palpable linguistic diversity of Lost in Translation, it cannot help but reflect a level of linguistic nonreciprocity. The fact that the film was released in Japan with its English title 
symbolises the state of play. Primarily through the vehicle of cinema itself, English has become the lingua franca of the globalised world. In this context, the film's lack of subtitles does not suggest a willingness to embrace the foreignness of Japanese language. Rather, it needs to be interpreted in relation to Anglo-American audiences' impatience with subtitles and a means by which - for these same audiences - character identification proceeds exclusively along American rather than Japanese lines.

\section{Mouthing silence}

The linguistic dimension of polyglot films like Lost in Translation and Le Mépris is best understood against the backdrop of cinema's historic relationship to translation. Indeed, film's initial, silent phase is particularly significant in this regard. While it may seem odd that the present discussion of multilingualism and polyglot cinema suddenly diverts towards a period of silence, it is well to remember that silent film was anything but. ${ }^{4}$ True, audiences could not hear the people and places they viewed on screen. However, it is now well documented that silent films were underpinned by a plethora of localised sounds - from musical scores and sound effects to live dubbing by actors positioned behind the screen ('talker pictures') and live interpreters or lecturers in front.

In this section I intend to outline some early film history in order to contextualise the above analysis of the polyglot genre. Asserting the thorough internationalism of the silent era, I propose that issues of translation constitute a necessary, formative part of the cinematic condition, and have done since the inception of this institution at the end of the $19^{\text {th }}$ century. In the US, for instance, as in many countries, French films (mainly from Pathé) dominated until around 1908 (Abel 2001: 150). Indeed, the worldwide network of Lumière representatives ensured that the majority of audiences across the globe first encountered film as a foreign product. In Australia, for instance, the Lumière agent Marius Sestier was amongst the first to introduce film, arriving in Sydney in 1896 (Shirley \& Adams 1983: 7). In September that year, Sestier joined forces with Australian photographer Walter Barnett and opened the 'Salon Lumière', emphasising the French branding of his product.

The speed at which the Lumières were able to achieve a global presence - reaching five continents in just three months (Jeancolas 1996: 16) - was truly remarkable. Interestingly, their operation did not simply screen French films in foreign locales. Perhaps the key to their success was the fact that Lumière agents were trained as both projectionists (Cinématographe operators) and filmmakers. Audiences were offered a mix of international and local 'views', such as Sestier's popular filming of Australia's 1896 Melbourne Cup. Lumière films produced in foreign locations were then sent back to France for inclusion in the house catalogue available to agents worldwide (Jeancolas 1996: 17). In keeping with the 
Lumière brand, the majority of these films were of a realist nature, documenting landscapes, scenes from daily life, religious ceremonies, parades and current events. The 'panorama' was a particularly popular genre that consisted of footage shot from moving vehicles such as trains, trams and boats (Jeancolas 1996: 14).

The internationalism of the Lumière operation was characteristic of the cinema's global preoccupation during the silent era. Audiences around the world were quite accustomed to viewing foreign films shot in diverse settings. ${ }^{5}$ In this sense, exoticism was as much a part of the attraction as any appeal to commonality. However, it was the cinema's universal dimension that was repeatedly stressed in the rhetoric surrounding this new art form and entertainment. Promoters were quick to recognise the benefits of couching the cinema's internationalism in terms of its democratic and diplomatic potential. This emphasis upon unity and togetherness advanced the notion that the cinema was actively traversing geographic and economic or class barriers. A particularly potent metaphor emerged whereby silent cinema was understood to speak a universal, non-verbal language and to exist therefore in a realm beyond translation.

Historical records reveal, however, that the internationalism and supposed universalism of the silent era was in fact underwritten by a vast array of translation practices both linguistic and ideological in nature. During this period translation took many forms encompassing the textual, aural and visual realms. Intertitles were swapped, films were accompanied by live commentators/interpreters, and whole storylines were transformed. Indeed, intertitles were subject to both inter- and intra-lingual translation. For example, US film intertitles were altered for export to England and Australia, as well as foreign-language markets. Indeed, the degree of translation required to preserve the myth of universalism was phenomenal, as is revealed in Ruth Vasey's impressive study The World According to Hollywood, 1918-1939 (1997).

Vasey's account documents in detail many of the non-linguistic forms of translation that took place during the silent era. According to Vasey, cultural translation affected the industry on a multitude of levels, from production through distribution to the point of exhibition. The success of Hollywood products in foreign markets depended largely on public-relation efforts, which resulted in major pre-production changes in relation to content regulation. Typical plot modifications often involved character ethnicity and national setting. Vasey (1997: 59) refers to the "Russification of the villain" - a typical strategy employed in order to minimize offence in lucrative European markets such as Germany and France. Sometimes films were produced in separate versions for foreign and domestic markets, using alternate takes or protection shots and often deleting scenes likely to cause offence (Vasey 1997: 54-64).

During the distribution phase, censorship was routinely performed by both exporters and importers. Intertitles were adapted to accommodate varying religious and moral codes while entire plots could be re-worked through 
the editing and re-arrangement of shots (Vasey 1997: 64). Unofficial censorship was common amongst film exhibitors themselves, who catered their screenings to particular audience groups. In fact, alteration at the level of exhibition was incredibly diverse and motivated by many factors beyond that of censorship. Films were regularly shortened (as in Switzerland) or lengthened (as in Germany) to suit national tastes, while in Brazil, projection speeds were usually slowed to allow for low-levels of audience literacy (Vasey 1997: 68-72). In addition, films were mediated via a broad range of musical, sound and spoken accompaniments.

In relation to translation, the most significant of these methods were live dubbing and interpreting. Non-mechanical, live dubbing practices involved the presence of behind-the-scene actors or house operators (film 'talkers') who attempted to augment silent film by reproducing character dialogue and sound effects, adding to realism and comprehension levels (Klenotic 2001). The film lecturer or narrator was another popular aid. This tradition flourished during silent film's initial years, easing the transition from fairground and magic lantern lecture traditions (Crangle 2001: 44-47). It also proved immensely popular in particular national contexts such as Japan, where narrators referred to as katsuben or benshi ${ }^{6}$ elaborated the stories of silents, reading prepared scripts and translating foreign intertitles. The role of the katsuben developed to such an extent that their popularity rivalled that of the film stars themselves and even survived the advent of sound (Bernardi 2001: 35-37). Japan's neighbour Korea developed a similar tradition of live orators referred to as byonsa (Hu 2002), while in the US some theatres catered to immigrant audiences by offering intertitle interpreters known as spielers (Ross 1998: 21).

Vasey's investigation into the influence of foreign markets on the historical development of American film reveals the extent to which translation formed an integral part of the industry as a whole. Her many examples of content regulation suggest that, even viewed in isolation from written and spoken referents, images are always subject to ideological framing. In this sense, the particularly prevalent claim that silent film represented a form of direct, unmediated communication - as proposed, for instance, by early film theorist Béla Balázs (Hansen 1991: 188) ${ }^{7}$ - is discredited, even before the concept of 'silent' film is itself disputed. This myth helps to clarify the issues at stake within the translation contract, signalling the inseparable nature of language and ideology. Originating in the silent era, the notion that film somehow exists 'beyond' translation continues today, with the most extreme example being the dialogue-free, environmental documentary type film that began with Koyaanisqatsi (dir. Godfrey Reggio, 1983). ${ }^{8}$ As a result the actual, everyday operations of translation are forced underground and made invisible, true to the rules of classical narrative cinema. In the context of such widespread disavowal by the industry, the question remains: how to approach the anomaly of the polyglot film, which made its noisy debut during sound cinema's first experimental years? 


\section{Polylingual promise}

The US Lost in Translation theatrical release trailer ends with the tagline: "Sometimes you have to go half way around the world to come full circle". Ultimately, Bob and Charlotte's tandem journeys of self-discovery are initiated through their encounter with the foreign. Together, they find themselves temporarily stranded in the alien territory of Tokyo's mega-city. Unable to speak the language or decode the culture, their sense of dislocation cannot be overcome through any form of language transfer. Together they reflect upon the experience of difference itself - of being caught in-between two cultures, traversing two languages. Ultimately, this sense of cultural disjunction or incommensurability articulates a site of untranslatability.

When Bob makes a guest appearance on a local talk show (hosted by real-life talk show personality Matthew Minami), he appears utterly at sea despite the presence of the interpreter. The talk show proves a particularly vernacular and culturally dense experience. Language cannot be divorced from nationally inflected attitudes to humour, fashion and the body. Like Bob, the Western audience is alienated, unable to make sense of the un-subtitled Japanese dialogue and over-the-top talk show antics. Interestingly, Coppola chose to keep the American actors in the dark as to the meaning of most of the Japanese dialogue in the film. She states: "I like the fact that the American actors don't really know what's going on, just like the characters" (Rich 2003: 1). In Le Mépris, the viewer is alerted to gaps in meaning that extend well beyond levels of linguistic capability. Ultimately, it is husband and wife sharing a native tongue that find they can no longer communicate effectively. In one of the film's final scenes, when Paul asks Camille why she no longer loves him, she replies that she will never tell him. Language is revealed as tool and weapon, a form of ideological navigation. Meanwhile, disarticulation and untranslatability emerge as unavoidable conditions of human existence.

According to Jacques Derrida, untranslatability is a core component within all forms of translation. Translation describes a central paradox, in that it is both necessary and impossible. Derrida proposes that translation is never successful, but rather, is an inherently flawed practice that is doomed to failure. While it strives towards an ideal of universality - the utter transferability of meaning - in the process it inevitably exposes the singularity of language, exemplified in the untranslatability of proper names. This is translation's 'double bind'. Derrida (1985: 102) writes that "this desire is at work in every proper name: translate me, don't translate me". "The event of a translation, the performance of all translations", he continues, "is not that they succeed. A translation never succeeds in the pure and absolute sense of the term. Rather, a translation succeeds in promising success, in promising reconciliation" (123). Here, it is the promise or presentiment of a future event, which describes the radical potential of translation. In attempting to translate, to make the foreign familiar, difference is inevitably reaffirmed and 
accentuated. In this sense, translation is inherently deconstructive, undoing as it does.

This deconstructive potential is most likely the reason polyglots remain so rare, despite dating back to the earliest days of sound film. Polyglots effectively unravel the cinema's claims to universalism, through which it has been able to broaden its consumer base by homogenising ethnic and class difference. According to Miriam Hansen (1991: 78), the universallanguage metaphor became a means by which to shape mass-culture according to middle-class (as opposed to working-class) sensibilities and aspirations, and to ensure Hollywood's hold on world film markets. This sentiment is echoed by Ella Shochat \& Robert Stam (1985: 36), who assert that "Hollywood both profited from and itself promoted the universalisation of the English language as the idiom of speaking subjects". At both a domestic and international level, the universal-language myth was deployed as a tool of control and colonisation. In this context, it is easy to see why polyglots present such a potential threat to commercial filmmaking.

When US talkie The Jazz Singer (1927) screened around the world, audiences came out in droves to witness the novelty of sound. However, the new cohesion promised by cinema - through the marrying of sound and image - was compromised on many levels. Synchronisation technology was still rudimentary, often diminishing rather than enhancing the sense of realism achieved. Many directors and critics resisted the transition to sound, fearing the loss of a sophisticated film language in favour of technological novelty. America's leading silent directors, including Borzage, Ford, Stroheim, Sternberg and Vidor, continued making silents well after the advent of talkies, utilising ever-more accomplished methods to approximate dialogue rather than risk the confines and pitfalls of early sound experimentation (Everson 1998: 337).

It was soon discovered that sound served to fortify, if not construct outright, definitive geographic and temporal borders, firmly locating narratives in precise locales, just as voices found themselves anchored to specific bodies. The results were disastrous for many actors whose voices or musical abilities did not match their on-screen personas (Fox 1972, Eyman 1997), as portrayed in the light-hearted antics of Singin' in the Rain (dir. Stanley Donen, 1952). Foreign characters were doubly problematic. How could foreignness be conveyed if not through language? Nationality had to become a hyper-visual spectacle conveyed through appearance (foreign 'types'), excessive mannerisms and clichéd gestures (Maurice 2002: 42). According to Robert Spadoni (2003: 6), sound cinema resulted in a renewed sensitivity to the medium and materiality of film. The technological nature of synchronisation meant that viewers "were suddenly much more aware of Hollywood films as manufactured objects" (ibid.). When slip-ups occurred the effect was doubly damaging. The root of the problem was synchronisation itself. Audiences complained that actor's voices sounded 'unnatural', and that they always issued from the same spot (the loudspeaker) no matter where characters were situated on screen (6-7). 
Mary Ann Doane (1985: 171) notes that the "recorded voice, which presupposes a certain depth, is in contradiction with the flatness of the twodimensional image". Referring to the work of sound theorists Hans Eisler and Theodore Adorno, she suggests that the audience is "always aware of this divergence, of the inevitable gap between the represented body and its voice" (ibid.). Rick Altman (1980) proposes that all sound film is in essence a form of ventriloquism. As sound is always produced separately to the film image, moving lips on screen only appear to produce words. In reality they mouth silence and the sound track is externally located, outside or beyond the on-screen body. This survey of critical voices points to an overall crisis of authenticity encapsulated in the sound film. Despite expectations, the coming of sound was experienced more as a sensation of loss than completeness. The audibility of language difference also signalled potential economic losses in both foreign and domestic markets (Gomery 1985). With the introduction of sound, the spotlight was thrown onto a subject the film industry as a whole would rather have kept forever shrouded. Translation became the hot topic of the day, requiring an urgent solution. Alongside early dabbling in subtitling and dubbing techniques, ${ }^{9}$ the industry devised two utterly divergent approaches: polyglots and multiple language versions (MLVs).

Polyglot films approach translation in a radically upfront manner, by scripting language contact into their narrative, dialogue and setting. In this sense, they accentuate and celebrate linguistic diversity. Allo Berlin? Ici Paris! or Hallo Paris? Hier spricht Berlin! (dir. Julian Duvivier, 1931-1932) incorporates both French and German dialogue and was released in both markets without the aid of subtitles (Garncarz 1999: 256). The plot concerns a love story between telephonists in Berlin and Paris, who must both struggle to be understood in each other's tongue. In contrast, MLVs sought to suppress awareness of translation by shooting films in various language versions, re-using sets (up to fourteen times) whilst replacing actors and crews (Betz 2001: 28). According to Joseph Garncarz (1999: 253), the "central characteristic of the MLV is that the actors in each version themselves speak the language of the country to which the version is being exported".

These two contemporaneous practices represent diverse solutions to the so-called 'language problem'. Polyglot films celebrate the multiplicity of language by making (mis)translation central to the film's rationale. As Lost in Translation and Le Mépris reveal, this emphasis upon language difference makes polyglots attuned to untranslatability, cultural disjunction and gaps in meaning. In contrast, MLVs instituted an all-encompassing form of translation which sought to minimise both national and linguistic markers. In a sense, MLVs dubbed the body of the actor rather than merely his or her voice (Vincendeau 1988: 34). In some instances, multi-lingual stars were able to retain their parts across a number of different language versions. For example, the German-born Lilian Harvey played opposite German and French co-stars in Die Drei von der Tankstelle / Le Chemin du Paradis (1930) (Garncarz 1999: 265). However, the more usual practice was to choose native-speaking stars and to import crews, scriptwriters and directors. 
While polyglot films were always a rarity, MLVs dominated in Europe and the US from 1929 to 1932 , constituting the most widely practiced solution to the problem of the international comprehensibility of the talkie. Production declined dramatically after 1933 (Vincendeau 1988: 39), although MLVs continued to be made sporadically throughout subsequent eras, at least until the late 1970s (Betz 2001: 28). ${ }^{10}$ The reasons for the decline of the MLV are complex and somewhat contested, relating to economic, artistic and social pressures (Garncarz 1999, Vincendeau 1988). Eventually, they were overtaken by subtitling and dubbing - the two most prevalent techniques in use today. In contrast, the polyglot genre is thoroughly intermeshed with a range of translation devices, frequently employing subtitles (Le Mépris), dubbing (Voice of Brazil) ${ }^{11}$ and interpreters (Le Mépris, Lost in Translation).

\section{Conclusion}

According to Shochat \& Stam (1985: 41-45), the eccentricities of film title translations provide a succinct expression of the complications, imperfections and approximations that necessarily beset all translation. Constituting an "especially privileged locus in a film's discursive chain", titles shape both the reception and interpretation of films, acting as 'hermeneutic pointers' that "promise, prefigure and orient" (43). As proper names, they both defy and demand translation, exposing a pre-existing level of arbitrariness. In this context, the fact that Lost in Translation retained its English title when released in Japan is particularly telling. Although it does so with a level of self-reflexiveness, Lost in Translation cannot help but reveal the manner in which Hollywood employs language to "colonise the subconscious of multiple cultures" (53).

Although backed by Japanese distributor Tohokushinsa, Lost in Translation clearly testifies to the global dominance of American values, themes and idioms. Note that Bob Harris is a Hollywood actor who is in Japan being paid two million dollars to endorse a Japanese whiskey, and that this plot detail is based on the real-life experience of Francis Ford Coppola who in fact directed a Suntory whiskey commercial. ${ }^{12}$ However, the linguistic diversity of this film - its fictionalised points of language contact - do indeed contain a radical potential, deploying the spectre of (mis)translation to expose the shaky ground upon which claims to universalism are necessarily staked. Translation sets in motion a deconstructive dynamic that effectively destabilises both the departure point and final destination of the various Englishes that make their way to the big screen.

With the coming of sound in the late 1920s, the silent era's extensive operations of translation and mediation no longer proved adequate. A more standardised system was required in order to re-build the illusion of unity shattered by the undeniable reality of language difference. Although it encountered various resistances (such as Film Europe), ${ }^{13}$ the American film 
industry emerged as the dominant player in the world film market. However, a plethora of translation tools were required to support this position of supremacy, such as live narrators, multiple-language versions, subtitling and dubbing. As Hamid Naficy (1996) suggests, languages in-translation are radically unpredictable, affected by accents, cultural overdetermination and the possibility of miscommunication. Recalling first-hand the experience of viewing Iranian-dubbed American films, Naficy (1996: 13) refers to films intranslation as 'hybrids' that wield a performative, excessive power.

Through its title, Lost in Translation is prefaced by negativity. From the outset this film tempers the concept of translation via a sense of loss, privation and dispossession. The proliferation of languages brought about by the introduction of sound to the cinema also resulted, ironically, in an experience of lack. In this sense, the talkie fell far short of audience expectations. The universal-language metaphor was called to task, with audiences desiring almost the antithesis of translation - its promised 'beyond'. To a degree, this call was answered by the polyglot, which represents translation in reverse. Polyglots allow the babble or confusion of multiple languages to be heard, suggesting the ultimate untranslatability of difference. In drawing attention to the presence of linguistic diversity, polyglots celebrate the radical, deconstructive potential of translation as a form of undoing, identifying miscommunication, error and unpredictability as valid sites of production and signification.

\section{Bibliography}

Abel, Richard \& Rick Altman (eds) (2001). The Sounds of Early Cinema. Bloomington/Indianapolis: Indiana UP.

Abel, Richard (2001). "“That most American of attractions': the illustrated song”. Abel \& Altman (2001), 143-155.

Altman, Rick (1980). "Moving Lips: Cinema as Ventriloquism". Yale French Studies 60, 67-79.

Altman, Rick (2001). "The Living Nickelodeon". Abel \& Altman (2001), 232-240.

Anderson, J. L (1992). "Spoken Silents in the Japanese Cinema; or, Talking to Pictures: Essaying the Katsuben, Contexturalizing the Texts". Arthur Nolletti, Jr. \& David Desser (eds). Reframing Japanese Cinema: Authorship, Genre, History. Bloomington/Indianapolis: Indiana UP, 259-311.

Bernadi, Joanne (2001). Writing in Light: The Silent Scenario and the Japanese Pure Film Movement. Detroit: Wayne State UP.

Betz, Mark (2001). "The Name above the (Sub)Title: Internationalism, Coproduction, and Polyglot European Art Cinema”. Camera Obscura 46(1), $1-45$.

Burch, Noël (1983). “Approaching Japanese Film”. Stephen Heath \& Patricia Mellencamp (eds). Cinema and Language. Los Angeles: American Film Institute/University Publications of America, 79-96.

Chow, Rey (1995). Primitive Passions: Visuality, Sexuality, Ethnography, and Contemporary Chinese Cinema. New York: Columbia UP.

Crangle, Richard (2001). "'Next Slide Please': The Lantern Lecture in Britain 18901910”. Abel \& Altman (2001), 39-47. 
Danan, Martine (1999). "Hollywood's Hegemonic Strategies: Overcoming French Nationalism with the Advent of Sound". Higson \& Maltby (1999), 225-248.

Delabastita, Dirk (1990). "Translation and the Mass Media". Lefevere \& Bassnett (1990), 97-109.

Derrida, Jacques (1985). The Ear of the Other: Otobiography, Transference, Translation. Texts and Discussions with Jacques Derrida (ed. Christie McDonald) (tr. Peggy Kamuf \& Avital Ronell). Lincoln/London: University of Nebraska Press.

Doane, Mary Ann (1985). "Ideology and the Practice of Sound Editing and Mixing". Teresa de Lauretis \& Stephen Heath (eds). The Cinematic Apparatus. Houndmills, Basingstoke/London: Macmillan, 47-56.

Durovicová, Natasa (1992). "Translating America: The Hollywood Multilinguals 1929-1933”. Rick Altman (ed.). Sound Theory/Sound Practice. New York/London: Routledge, 138-153.

Everson, William K. (1998). "The Art of the Subtitle". American Silent Film. New York: Da Capo Press, 126-141.

Eyman, Scott (1997). The Speed of Sound: Hollywood and the Talkie Revolution. New York: Simon \& Schuster.

Fox, Julian (1972). "Casualties of Sound. Part Two: Silence not so Golden”. Film \& Filming 19(2), 32-40.

Gambier, Yves \& Henrik Gottlieb (eds) (2001). (Multi)Media Translation: Concepts, Practices, and Research. Amsterdam/Philadelphia: John Benjamins.

Garncarz (1999). "Made in Germany: Multiple-Language Versions and the Early German Sound Cinema". Higson \& Maltby (1999), 249-273.

Gomery, Douglas (1985). "Economic Struggle and Hollywood Imperialism: Europe Converts to Sound". Elisabeth Weis \& John Belton (eds). Film Sound. New York: Columbia UP, 25-36.

Hansen, Miriam (1991). Babel \& Babylon: Spectatorship in American Silent Film. Cambridge, Mass./London: Harvard UP.

Haslem, Wendy (2004). "Neon Gothic: Lost in Translation". Senses of Cinema 31 (April-June). On line at: http://www.sensesofcinema.com (consulted 09.02.2005).

Higson, Andrew \& Richard Maltby (eds) (1999). "Film Europe" and "Film America”: Cinema, Commerce and Cultural Exchange 1920-1939. Exeter: University of Exeter Press.

Hu, Brian (2002). "Cinema Review: Traditional Eastern Film, Superlative Sonic Source. Benshi meets Byonsa: Silent 'Plus'”. The Daily Californian, Sept. 19. On line at: http://www.dailycal.org (consulted 20.01.2004).

Ivarsson, Jan (1995). "The History of Subtitles". Translatio 10, 294-302.

Jäckel, Anne (2001). "Shooting in English? Myth or Necessity?". Gambier \& Gottlieb (2001), 73-89.

Jeancolas, Jean-Pierre (1996). "Planet Lumière". Colin Nettelbeck, Jane Warren \& Wallace Kirsop (eds). A Century of Cinema: Australian and French Connections. Melbourne: University of Melbourne Press, 9-20.

Klenotic, Jeffrey (2001). “'The Sensational Acme of Realism': 'Talker' Pictures as Early Cinema Sound Practice”. Abel \& Altman (2001), 156-166.

Lefevere, André \& Susan Bassnett (eds) (1990). Translation, History and Culture. London/New York: Pinter Publishers.

Lev, Peter (1993). "Art and Commerce in Contempt". The Euro-American Cinema. Austin: University of Texas Press, 83-89.

Lowry, Edward (1983). "Edwin J. Hadley: Travelling Film Exhibitor". John Fell (ed.). Film Before Griffith. Berkeley: University of California Press, 131-143. 
Maltby, Richard \& Ruth Vasey (1994). "The International Language Problem: European Reactions to Hollywood's Conversion to Sound". David W. Ellwood \& Rob Kroes (eds). Hollywood in Europe: Experiences of a Cultural Hegemony. Amsterdam: VU University Press, 68-93.

Maurice, Alice (2002). “'Cinema at Its Source': Synchronizing Race and Sound in the Early Talkies". Camera Obscura 49(1), 30-71.

Naficy, Hamid (1996). “Theorizing 'Third-World' Film Spectatorship”. Wide Angle 18(4), 3-26.

Nornes, Abé Mark (1999). "For an Abusive Subtitling”. Film Quarterly 52(3), 17-34.

Rich, B. Ruby (2004). "To Read or Not to Read: Subtitles, Trailers, and Monolingualism". Atom Egoyan \& Ian Balfour (eds). Subtitles: On the Foreignness of Film. Cambridge, Mass./London: MIT, 153-169.

Rich, Motoko (2003). "What Else Was Lost in Translation". The New York Times, Sept. 21, Section 9, 1.

Rich, Motoko (2004). "Land of the rising cliche". The Age, Jan. 17, A2, 3.

Ross, Steven J. (1998). Working-Class Hollywood: Silent Film and the Shaping of Class in America. Princeton: Princeton UP.

Schaber, Bennet (2005). "Found in Translation: Some Tendencies in Recent Global Cinema". Cinemascope 1. On line at: http://www.cinema-scope.net (consulted 03.02.2005).

Shirley, Graham \& Brian Adams (1983). Australian Cinema: The First Eighty Years. Sydney: Angus \& Robertson/Currency.

Shochat, Ella \& Robert Stam (1985). "The Cinema After Babel: Language, Difference, Power". Screen 26(3-4), 35-58.

Spadoni, Robert (2003). "The Uncanny Body of Early Sound Film". The Velvet Light Trap 51 (Spring), 4-16.

Thompson, Kristin (1999). "The Rise and Fall of Film Europe". Higson \& Maltby (1999), 56-81.

Vasey, Ruth (1997). The World According to Hollywood, 1918-1939. Wisconsin: University of Wisconsin Press.

Vincendeau, Ginette (1988). "Hollywood Babel". Screen 29(2), 24-39.

Wahl, Chris (2005). "Discovering a Genre: The Polyglot Film". Cinemascope 1. On line at: http://www.cinema-scope.net (consulted 03.02.2005).

1 Reprinted in Melbourne's The Age newspaper (M. Rich 2004). Lost in Translation typifies the co-production and distribution practices of contemporary Hollywood cinema in relying on the 'semi-independent' system. The film had the backing of numerous independent companies (internal and international) including American Zoetrope and Elemental Films, as well as the Japanese distributor Tohokushinsa. The main distributor, however, was Focus Features, which is a subsidiary company of Universal Pictures.

2 Rich's comments are supported by European language scholar Anne Jäkel who notes the increasingly multilingual nature of contemporary film promotion and production. See Jäkel (2001: 85).

3 Mark Betz notes that internationally co-produced films are often released simultaneously in a variety of versions tailored to different national contexts. For instance, La Nuit américaine / Day for Night (dir. François Truffaut, 1973) was a French/Italian/UK/US co-production which in its first-run release in the US and Great Britain was shown in a dubbed version. Thus, Betz suggests that the Englishdubbed version of this film is perhaps more 'authentic' than a subtitled print, despite the fact that art-house, foreign-language film audiences in the US/UK tend to equate 
subtitles with authenticity. Betz (2001: 4) states, "from an archival standpoint, there really is no version of a film 'as originally produced' to preserve ... except perhaps for the unviewable in-camera negative, the only use for which is to strike the positive prints that constitute the bulk of every film archive's holdings".

${ }^{4}$ For a particularly useful anthology on sound in 'silent' film, see Abel \& Altman (2001).

5 In addition, many films produced entirely for domestic consumption included footage shot in foreign locations. See Lowry (1983: 138).

6 According to J. L. Anderson (1992: 260), katsuben is the more specific term, constituting a portmanteau word that combines katsudo shashin (moving pictures) and benshi. For further information on the katsuben tradition, see Anderson (1992), Bernardi (2001: 33-37), Burch (1983), and Nornes (1999).

7 In 1924, Balázs writes: "For on the motion picture screens all over the world we currently witness the development of the first international language: that of facial expression and physical gestures" (qtd. in Hansen 1991: 188).

8 Koyaanisqatsi was the first in the "qatsi' trilogy and spurned a number of followon features including most notably Baraka (dir. Ron Fricke, 1992). Thanks to Adrian Martin for suggesting the relevance of this genre in correspondence through the Film-Philosophy discussion salon, on line at: http://www.film-philosophy.com.

9 Jan Ivarsson (1995) traces the use of subtitles as far back as 1909.

${ }^{10}$ According to Betz (2001: 28), "MLVs have continued to be made in Europe after the Joinville era and through the postwar period". His examples include Renoir's Elena et les hommes / Paris Does Strange Things (1956) and Werner Herzog's Nosferatu (1979), which was "shot with the same cast performing separate German and English versions" (Betz 2001: 28).

${ }^{11}$ According to Shochat \& Stam (1985: 51), Voice of Brazil (Voz do Brasil) is centred around the dubbing of an American film in a Brazilian sound studio.

${ }^{12}$ See the "Trivia" section for Lost in Translation on The Internet Movie Database, on line at: http://www.imdb.com (consulted 01.05.2005).

${ }_{13}$ The 'Film Europe' movement of the 1920s sought to promote pan-European industry activity, alliances and audiences in an effort to counter US hegemony over world film markets. Recognising the unparalleled size and enthusiasm of America's domestic market, Film Europe attempted to organise its numerous nation-states into one unified 'domestic' market. Kristin Thompson (1999: 78) suggests that this movement "helped form the basis for the formations of the Council of Europe, the Common Market and the developing European Union". For a detailed analysis of the Film Europe phenomenon, see Higson \& Maltby (1999). 